\title{
Enterprise gamification systems and employment legislation: a systematic literature review
}

\section{Sean Hinton}

Spark New Zealand

seanahinton@gmail.com

\section{Lincoln Wood \\ Otago University}

\section{Harminder Singh}

Auckland University of Technology

\section{Torsten Reiners}

Curtin University

\section{Abstract}

A recent innovation in employee motivation systems is the introduction of 'gamification', which refers to the use of game design mechanics and principles to influence behaviour to enhance staff motivation and engagement. Enterprise gamification systems aggravate the differences in information availability between employers and employees, and employees who may be forced to adopt such systems may be placed under stress, worsening employment relationships in the workplace. Therefore, this research examines the potential legal implications of gamified employee motivation systems. This study undertook a systematic review of enterprise gamification and then used thematic analysis coupled with a review of legislation to examine whether gamification in workplaces meets the legal obligations of employers under their 'duty of good faith' in the New Zealand context. We find that carefully designed enterprise gamification systems should provide sufficient information and clarity for employees and support positive employment relationships. Deployments of enterprise gamification systems should be carefully planned with employee consultation and feedback supporting the introduction of an enterprise gamification system. Future research should look beyond the 'good faith' obligation and examine the relationship between gamification systems and the law on personal grievances.

Keywords Gamification, performance management, legal, employment relationship, good faith, game mechanics

\section{Introduction}

Performance monitoring of employees - "the observation, examination, and/or recording of employee work-related behaviors" (Stanton, 2000, p. 87) - is used to motivate employees so as to increase their work output, reduce costs and enhance customer satisfaction (Alder, 1998; Chalykoff and Kochan, 1989; Jeske \& Santuzzi, 2015; Annakis et al., 2011). Employees too are aware that some data about them can be collected and used to evaluate whether they are meeting key performance indicators (KPIs) (e.g., monthly sales targets), and thus be rewarded with financial rewards, tangible services or other benefits (Herzberg, 1966; Kalleberg and Loscocco, 1983; Mottaz, 1988). Setting KPIs and monitoring whether employees attain these requirements could be termed a 'passive' approach to performance monitoring. Traditionally, the transactional nature of the enterprise resource planning systems which dominate 
workplaces has allowed operational performance data to be captured in real-time and compared to KPIs (Alder, 1998). Such systems have thus emphasised efficiency gains.

Contemporary information systems have afforded new uses of data that push beyond such backwards-looking passive systems, towards more active monitoring and adjustment of circumstances in a way that encourages employee participation. The dominant form of these new employee performance monitoring systems is 'enterprise gamification systems'. Such systems use game-based principles (Deterding, Dixon, Khaled, and Nacke, 2011a) to shift employee behaviour (Reiners and Wood, 2015) so that the outcomes transcend efficiency improvements and may influence employee behaviour in more subtle ways compared to existing performance management systems (Callan, Bauer, and Landers, 2015). Enterprise gamification may also be more effective as it enables organisations to stimulate individuals' intrinsic motivation as well (Herzig, Ameling, and Schill, 2015).

This shift towards the use of game design principles (Sicart, 2008) in performance monitoring systems is fairly recent, and with early research still focusing on how to develop KPIs connected to relevant activities (Conley and Donaldson, 2015). Most studies on performance monitoring systems examine traditional performance monitoring systems, which are relatively transparent and passive, often logging time spent on particular tasks, or when certain activities are taken (Jeske and Santuzzi, 2015). In such systems, data on a limited number of performance indicators is collected and analysed, with focus given to performance against a minimum standard for relatively simple KPIs (e.g., minimum calls per hour) with the ability to connect this to extrinsic motivators; e.g., financial rewards or bonuses (Wickham and Collins, 2004). Emerging enterprise gamification systems differ from these systems in two ways. First, employees can be closely monitored, with more data collected and analysed in greater detail, and performance data can be relayed to employees instantly (e.g., through leaderboards). Second, such systems may encourage employees to undertake activities that, while being playful or game-like, provide employers more oversight and control of employees' actions.

The move towards the use of gamification for employee management has therefore been a shift away from the relatively transparent monitoring associated with traditional passive systems to an arguably more 'subversive' and manipulative system, where the 'play' is merely symbolic. The game design principles on which enterprise gamification systems are based are derived from games, where participation is clearly voluntary. However, this is not the case when game-like activities are used for performance monitoring. Further, gamification systems can disrupt the balance in workplace relationships, as they provide employers with overwhelmingly greater informational advantages above and beyond those conventionally available to employees.

The increase in the use of systems based on game-like activities for monitoring and manipulating behaviours in the workplace, therefore, is an area that professionals must better understand, because these systems may potentially change the balance of power between employees and managers. Employee motivation systems have been used in the past to influence behaviour, but the addition of game-like activities to them may, while increasing their attractiveness and ease of use, mask their potential to disturb the order in a workplace. However, even though employee motivation systems may now include gamification features, the legal requirements guiding their use are likely to be similar to what they were previously. Therefore, this paper's aim is to explore how game-like structures can make employee 
performance management more effective and what their implications are in workplaces. To examine this issue, this study asks two research questions:

RQ1. Given that enterprise gamification systems change the employer-employee relationship, are there any legal considerations that gamification system designers must take into account?

\section{RQ2. How should gamification principles be deployed in enterprise gamification systems?}

The current study was designed to address these questions by undertaking a systematic review in the New Zealand context. We first reviewed the literature on gamification, and next examined New Zealand legal cases pertaining to employment law and the concept of 'good faith'. These two sets of literature were thematically analysed to surface relevant concepts and relationships between the themes of 'good faith' in employment and gamification systems. The paper concludes by outlining considerations for designers of enterprise gamification systems and managers who use them.

\section{Background and related work}

To address the study objectives, a clearer theoretical background was required. Therefore, we searched for literature that provided an explanation of call centre work and job satisfaction, in addition to work more generally on gamification. The gamification literature we searched for focused on motivation and enterprise gamification (that is, influencing employees rather than customers) who have no choice to participate. Finally, we examined the role of employment law to understand the implications of these changing technologies in the workplace.

\subsection{Motivation}

Motivating employees is necessary when using human resources to carry out tasks. Motivation is defined as a force that energises behaviour, gives direction, and supports the tendency to persist (Bartol and Martin, 1998). Employee motivation levels and expectations can be changed by designing systems to encourage specific behaviours. Formally, motivation is usually manifested in workplaces in the form of performance monitoring systems which observe, examine, and/or record the work-related behaviours of employees (Stanton, 2000, p. 87); they are championed as improving work output, reducing costs and ensuring customer satisfaction (Alder, 1998; Chalykoff and Kochan, 1989). The nature and pervasiveness of monitoring solutions in organisations plays an important and influential role in the long-term wellbeing of an employee (Holman, 2002). Critics of performance monitoring, however, claim the practice is intrinsically threatening to workers as the information disparity between the employer and the employee has the potential to impact future remuneration or negatively influence social workplace relationships (Alder, 1998).

Smith, Carayon, Sanders, Lim, and LeGrande (1992) argue that the simple act of being monitored can increase an employee's emotional labour, resulting in higher degrees of depression, boredom, fatigue and anxiety. For example, greater dissatisfaction is observed among monitored employees (Aiello and Kolb, 1995). Conversely, in some instances, performance monitoring offers immediate feedback on employee performance and can result in positive job satisfaction (Chalykoff and Kochan, 1989; Jeske \& Santuzzi, 2015). However, it is important to consider how feedback is delivered, the intensity of monitoring, and its transparency among other employees (Carayon, 1994); positive influences on job satisfaction may drive not from the monitoring but from improved managerial practices (Annakis, Lobo, 
\& Pillay, 2011). This may also be relative to past work experience; where work involved greater autonomy previously, individuals may find that constant performance monitoring can generate negative feelings and acceptance (Jeske and Santuzzi, 2015). Feedback from performance monitoring systems also carries elevated importance to employees beyond personal growth, as meeting key performance indicators, e.g., monthly sales targets, can lead to financial rewards or benefits (Herzberg, 1966; Kalleberg and Loscocco, 1983; Mottaz, 1988). Therefore, managers must comprehend which rewards motivate employees, and how individual and organisational objectives may be balanced (Dunham, Grube, and Castañeda, 1994).

It is in this context that the emerging technologies of pervasive ICT systems and new sociomechanic approaches are colliding in the enterprise environment. One outcome is the rise of 'gamification' systems, which adapt existing work processes by adding game-like mechanics so as to modify behaviour to achieve performance- or motivation-focused outcomes. Paradoxically, this use of game-like mechanics may lead to non-playful and non-enjoyable outcomes at work (Callan et al., 2015). The gamification of processes encapsulates a form of electronic performance monitoring, and may bring about the "potential negative consequences of lower job satisfaction, affective commitment, lower perceived control and lower self-efficacy among employees" (Jeske and Santuzzi, 2015, p. 76).

\subsection{The case of call centres}

The call centre industry has highlighted the nature of the motivational problem as a fundamental trade-off between quantity and quality (of assistance) for employees (De Ruyter, Wetzels, and Feinberg, 2001), and the selection, implementation and use of management technology to facilitate the physical concentration and monitoring of staff (Mehrotra, 1997). Wallace, Eagleson, and Waldersee (2000) argue that call centre roles which focus on providing efficient and standardised performance in large quantities offer employees a transactional relationship with an organisation. These employees are tasked with resolving high call volumes comprised of repetitive and straightforward resolution processes. In these environments, management tends to use quantifiable indicators for performance appraisal (Wallace et al., 2000), supporting high volumes of service using scripts or flowcharts. Companies benefit as they can provide accurate and timely feedback on employee performance using performance monitoring technologies (Grant and Higgins, 1991). However, the adverse effects of these practices on employee stress and job satisfaction are often overlooked.

In part, this negligence is due to the obligations of managers to pursue low-cost operations through high productivity, and a prevailing attitude that churning through burnt-out staff will increase revenue (Lewig and Dollard, 2003). As a result, new employees, recruited in batches, are routinely favoured over existing staff; they provide fresh, enthusiastic, motivated customer service at low cost (Wallace et al., 2000). Volume-focused companies often take this approach, cognisant that they may be obligated to effectively forego three to four months wages annually in lost productivity for each new employee recruited (Holman, 2002). Deery and Kinnie (2002) argue that this mentality contributes to a growing perception that call centre jobs are 'deadend' and are characterised by "low status, poor pay and few career prospects" (p. 3).

Misalignment of organisational objectives and the motivational requirements of the individual call agent (Wallace et al., 2000) can develop from the outset of the employment relationship, as companies actively seek employees with high levels of intrinsic motivation to provide 
quality services, but go on to overwhelm them with high call quantity and limited autonomy. The dissonance created by these objectives emerges as staff struggle to resolve dynamic complaint calls when constrained by pre-scripted resolutions. Bandura, Freeman, and Lightsey (1999) argue that fostering dissonance and relying on 'surface acting' (a mental state of projecting, yet not experiencing, emotions) can lower an employee's sense of self-worth, leading to increased stress, and in extreme cases, symptoms of depression. Lewig and Dollard (2003) support this, noting emotional dissonance may "lead to lowered self-esteem, depression, cynicism, and alienation from work" (p. 368). Actions which inhibit empowerment directly influence employee stress and diminish motivation (De Ruyter et al., 2001). Chiles and Zorn (1995) note employment relationship empowerment consists of competence and authority. Competence is belief in ability to perform tasks proficiently; authority is the degree of autonomy when completing a task. Gamification research has largely overlooked these misalignments or has been limited to speculation around hypothetical employment scenarios (Callan et al., 2015).

\subsection{Gamification for behavioural change}

Some claim that gamification is not actually a new expression but one that simply encompasses many other parallel definitions; e.g., 'funware', 'behavioural games' and 'surveillance entertainment' (Deterding et al., 2011a). The concepts of 'game' and 'play' are distinct; games use rules system, often encourage competition, and have determined goals or objectives; in contrast, play is often experiential, is less guided or focused, and is often fun (Deterding et al., 2011a; Tekinbas, and Zimmerman, 2004). Gamification, as an academic term, has more to do with the concepts of "gamefulness" than that of "playfulness" through the application of game elements in non-game contexts (Deterding et al., 2011a).

This distinction is crucial, as methods of incorporating games into work environments have been attempted under labels including 'serious games', 'alternate reality games' and 'simulation games' (Reiners, Wood, Gregory, and Teräs, 2015). In each, the underlying game provides a context for successful integration, something gamification does not require. 'Enterprise gamification' is the emerging field of gamification systems deployed to manage day-to-day activities in the enterprise, often with a focus on efficiencies (Kumar, 2013).

Gamification drives behavioural change (Reiners and Wood, 2015, p. vi) through 'gamemechanics' while improving users' experience and increasing engagement (Deterding, Sicart, Nacke, O'Hara, and Dixon, 2011b). These mechanics are the structures and methods game designers use in traditional games to induce behaviour to achieve objectives. Reward systems (e.g., points, badges and leaderboards) are considered fundamental to gamified systems. Data is collected on what happens and when, so that a form of 'surveillance' takes place. This may be legitimised by reference to a data-driven approach that improves fairness, increases efficiency, and rewards workers that achieve required outcomes; however, some employees may fear that the system fails to meet their expectations in the workplace and does not respect their personal data (i.e., the system might go 'too far') (Ball and Margulis, 2011, pp. 122-123).

\subsection{User motivation through gamification}

Much gamification research is underpinned by self-determination theory (SDT) (Ryan and Deci, 2000), which focuses on 'growth tendencies' and psychological needs. SDT posits that two motivational principles determine behaviour. First, intrinsic motivation is driven by activities that induce interest in a user through an inherent drive to complete the task or to seek 
out and extend one's capacities. Second, extrinsic motivation is driven by external sources (e.g., rewards) which drive task completion. While many employment schemes currently use a number of extrinsic motivators, gamification processes often focus on harnessing the power of intrinsically motivated activities and deploying them in non-game contexts.

Cognitive evaluation theory (CET) offers three insights into how these systems perpetuate engagement. First, they offer a sense of autonomy, usually highest when participants are completing activities for their own interest; however, increasing choice and informational feedback along with non-controlling instructions can all elevate this sensation (Ryan, Rigby, and Przybylski, 2006). Second, they reward competence, a need for challenge and feelings of effectiveness (Gagné and Deci, 2005). Third, they promote relatedness, experienced when a person feels connected with others (La Guardia, Ryan, Couchman, and Deci, 2000). Human motivation is principally driven by intrinsic values and other crucial factors include mastery and purpose; in contrast, extrinsic rewards are limited relative to intrinsic motivators (Pink, 2010). Such attempts often build on sharing and connectedness between users and a sense of interest in the activity.

\subsection{Examples of Enterprise Gamification}

An enterprise gamification implementation of particular significance was undertaken in Disneyland Hotel in Anaheim (Lopez, 2011) to increase employee motivation, work output, and engagement. Digital screens displayed employee's work speeds on a leaderboard. Almost immediately, the opposite effect was observed: some workers insisted that publicly displaying 'work efficiency' generated undesired competition among staff, with those less proficient fearing that their performance would displease management. Another concern raised by the employees was their behavioural changes around bathroom breaks; to maintain a competitive edge over others on the virtual leaderboards, some staff felt it important to forgo these otherwise basic human necessities of bathroom breaks. It was blasted as an "electronic whip".

One commentator has claimed that 'gamification' is 'exploitationware'. Bogost (2011, para. 58) asserts that "[g]amification replaces these real, functional, two-way relationships with dysfunctional perversions of relationships. Organizations ask for loyalty, but they reciprocate that loyalty with shams, counterfeit incentives that neither provide value nor require investment." Gamification principles can change dynamics in employment relationships in ways that may not only be 'offensive' to employees, but which may fall foul of employment law.

Disneyland Hotel's gamified system raises some interesting questions about the relationship between employment laws and motivational tools embedded with the intent to manipulate behaviour. Gamification systems may seek to manipulate employees with less clear-cut incentives and carefully designed intrinsic motivators.

Just as Disney's Anaheim Hotel implementation highlights several unexamined realities in the context of employment relationships, we ask what exactly is the scope of an employer's obligation to provide a reasonable gamification implementation? Do enterprise gamification systems introduce new commitments to the employment agreement that parties must adhere to in order to fulfil their statutory obligations? To answer these questions, we turned to New Zealand legislation and common law that is relevant to employment. 


\subsection{Scope of Law}

Within the New Zealand ${ }^{1}$ judicial system, significant legislative acts expressly mandate the provision of 'good faith'. While good faith principles are practiced in other jurisdictions (e.g., Australia and Canada), this mostly relies upon the implied, and not express, covenant of good faith. A global examination of 'bona fides' would therefore be a sizeable challenge beyond the scope of this paper. It should be noted that, like New Zealand, many international legal systems are based on the same foundations and principles as those found in the United Kingdom's legal structure. Therefore, many issues and concerns are likely to translate when the applicable judicial systems are similar in nature.

The New Zealand-based obligations of 'duty of good faith' under section 4 of the Employment Relations Act 2000 (ERA) ("Employment Relations Act," 2000) were examined. We believe that this provides a sensible starting point for employers and employees in relation to enterprise gamification systems.

\section{New Zealand Employment Law}

\subsection{Good Faith Duty}

The New Zealand Employment Relations Act 2000 ("Employment Relations Act," 2000) is the principal piece of legislation relating to employment, covering all necessary legal obligations between business owners and employees who enter into an employment agreement; e.g., everything from the formation of the employment agreement, to trial provisions, and acceptable conduct from either party in the course of work duties. The goal stated in section 3 is "to build productive employment relationships through the promotion of good faith in all aspects of the employment environment and of the employment relationship" (emphasis added). Thus, good faith is at the heart of the legislation and influences virtually every provision in the act. While good faith is loosely defined in legislation, it broadly means "the duty to act in good faith is wider in scope than the implied mutual obligations of trust and confidence" (s 4(1A)(a)), while also requiring parties to an employment relationship to be "active and constructive in establishing and maintaining a productive employment relationship" (s 4(1A)(a)) ("Employment Relations Act," 2000).

Further refinement through common law occurred where it was stated that "good faith has more to do with notions of honesty, frankness and what lawyers call 'bona fides' rather than adherence to legal rules" (National Distribution Union Inc v Carter Holt Harvey Ltd, 2001). Special reference was made to section $4(1)(b)$ of the ERA, which outlines misleading and deceiving behaviour, clarifying that good faith is more "the spirit than the letter of the law". While the concept of good faith has been largely left to the New Zealand judicial system to define, assistance from similar legislations (e.g., from Canada and the United States) has been relied upon (NZ Amalgamated Engineering etc Union Inc v Carter Holt Harvey Ltd, 2002).

\footnotetext{
${ }^{1}$ Focusing on New Zealand law only is a limitation of the study, but we feel that it is an appropriate starting place because it is the legal system that is most familiar to us. We hope other researchers will build on our findings and extend the analysis of this topic to other legal systems, from both common and civil law traditions.
} 


\subsection{Employment relationship obligations}

Parties subject to an employment agreement must comprehend what constitutes "active and constructive" behaviour. Section $4(1 \mathrm{~A})(\mathrm{b})$ of the ERA mandates that parties must be considered to be "responsive and communicative"; section $4(1 \mathrm{~A})(\mathrm{c})$ declares that during the process of making decisions related to the continuation of an employment relationship, employers are obligated to provide employees with access to relevant information and an opportunity to comment on it. This obligation engrosses the "timely provision of useful information" (Baguley v Coutts Cars Ltd 2000). Furthermore, an employer was demonstrated to have an obligation to provide relevant information pertaining to the specifics of a complaint about an employee's behaviour beyond a generic disciplinary form (Gaut v BP Oil New Zealand $L t d, 2011)$. Section $4(1 B)$ of the ERA does place limitations on the information employers must provide when considering the continuation of employment; specifically, information may be withheld to comply with statutory requirements of confidentiality or where the risk exists that an employer may be unreasonably prejudiced. Equally, cautionary information relating to an employee's on-going employment must not be significantly different than what is used during the decision (Gwilt $v$ Briggs and Stratton New Zealand Ltd 2011). This was evident where one employer failed to provide relevant and sufficient information relating to redundancies (Nee $v$ TLNZ Auckland Ltd 2006); and another employer merely told a staff member of allegations instead of providing the original material the allegations were based on (Lawless $v$ Comvita New Zealand Ltd 2005).

If there is perceived employee confusion regarding the employment termination, employers must proactively correct any misguided beliefs; e.g., where an employee was informed by a third party his job had ended and the employer failed to make a correction (New Zealand Cards $L t d v$ Ramsay, 2012). Should an employee terminate their employment agreement as a result of an inaction against abusive behaviour, it is likely that a personal grievance raised for constructive dismissal will be successful (Shaw v Schering-Plough Animal Health Ltd, 2013).

\subsection{Balancing the power bias in employment relationships}

While it is clear there are responsibilities from the employer to the employee, employees also have responsibility to be 'communicative and responsive'; e.g., an employee that failed to adequately respond to inquiries about sick leave after being recognised at a sporting event during the time off (Taiapa $v$ Te Runanga O Turanganuia A Kiwa Trust, 2013). If an employee suspects trouble or potential issues they must act in a responsive and communicative fashion; e.g., a staff member accessed an employer's computer to verify their personal suspicions about the situation and later refused to comment on the information gathered (O'Hagan $v$ Waitomo Adventures Ltd, 2012).

\subsection{Misleading and deceiving}

Another significant obligation is under section 4(1) relating to behaviour "likely to mislead or deceive". Again, while no precise definition is provided it was later defined as "real risk, a substantial risk, or something that might well happen" ( $R v$ Pier 1987); alternatively, it could be held that it was "real or not remote chance or possibility regardless of whether it is less or more than 50 percent" (Global Sportsman Ltd v Mirror Newspapers, 1984).

\subsection{The case of Disneyland Hotel}

In the Disneyland Hotel scenario mentioned above, the first and most crucial issue to consider is whether the three major components of good faith (viz., being "active and constructive", 
"communicative and responsive" and "likely to mislead or deceive") are being adhered to by all parties.

We can deduce that a degree of communication breakdown occurred. Both parties would be obligated to be 'active and constructive'; therefore, appropriate discussion should occur and opportunities to raise concerns must be ensured. In many respects, a substantial failure to be 'active and constructive' may have already taken place. This could be through a lack of direct communication between the involved parties, and involvement of third-party media outlets that reported on employee concerns. A breakdown may have been exacerbated if the system was designed to hamper communication through facilitation of a one-way communication channel, or by disallowing a 'break' in being monitored during the work-day when staff wanted to voice concerns.

Second, both parties have an obligation to be 'responsive and communicative'. While this applies to the discussion with media outlets, it also extends to other aspects of the work environment. Should employees be placed in a situation where their employment is jeopardised, there is a reasonable expectation that information pertaining to their ongoing employment be conveyed in a way that is manageable and comprehensible, while providing a right of response. However, many gamification systems convey quantifiable performance metrics around 'efficiency' (e.g., time to complete tasks), but may neglect to convey qualitative measures (e.g., quality of outcome). Here, the measurement of efficiency during a 'review of work' is likely to be a mixture of both subjective and objective requirements, of which each party must be able to comment on in a way that is consistent with their legal obligations to be responsive and communicative.

Third, both parties must refrain from behaviour likely to "mislead or deceive". While inherently subjective, it will be viewed by judicial systems on a case-by-case basis; however, as in the Global Sportsman Ltd v Mirror instance, any misleading behaviour that holds a "real or not remote chance" of coming to fruition will likely lead to a breach of good faith. In Disney Anaheim's case, parties will need to monitor the performance systems to ensure they provide accurate data and that the informational displays adequately describe reported statistics. Publicly displayed performance monitoring must not be presented in a way that engenders an inaccurate impression to those monitored. This process is also important in other areas of employment law which mandate the fair treatment of all employees; e.g., statutory requirements around unjustified workplace disadvantages (Department of Labour, 2006).

From this case, we hope that it is clear that a poorly designed gamification system could present legal difficulties for the employer. This study thus asks: what are the key gamification principles that the system designer must consider and incorporate in a way to ensure that the system does not break 'good faith' principles?

\section{Research Methodology}

Addressing the research questions requires an overview of two bodies of literature: gamification and a body of legal cases. First, a structured analysis of the issues was undertaken by identifying relevant themes from the gamification literature that may pertain to employment. Second, we identified the relevant themes from important legal cases. These themes were then compared and possible areas of overlap identified. 


\subsection{Sampling}

Relevant gamification literature and legal cases were selected using a non-probabilistic, purposive sampling (Kumar, 2005) approach that allowed us focus on specific characteristics. This was particularly relevant as robust research on gamification is limited. Academic experts guided the selection of material and to help identify similar or relevant materials - a form of snowball or convenience sampling (Hallberg, 2006). The lead author used the ProQuest academic database with keyword searches (details in Appendix A), using terms such as gamification, motivational psychology, duty of good faith, and gamified system to find initial pieces of literature. The initial list was reviewed by the research team and additions were suggested. When initial items were identified, the lead author checked the citations for these articles to find related items, following the process outlined in Kumar (2005), and this list was checked by the research team.

As gamification is a relatively new topic, we included all articles identified and so the sample included both journal articles and conference papers. Our inclusion criteria required that the articles focus specifically on gamification and gamified systems; we excluded articles that focused on the related but different topics of 'serious games', 'alternate reality games' and 'simulation games' (Reiners, Wood, Gregory, and Teräs, 2015).

\subsection{Data analysis procedures}

A thematic content analysis approach was used identify persistent patterns and themes while also uncovering previously unknown links between the subjects (Birks and Mills, 2011). This involved identifying recurring patterns through an inductive analytic process. As more publications were added to the sample, further thematic analysis occurred; eventually, on the addition of the last articles, no new themes were emerging and existing themes were increasingly populated; this was treated as being a point of theoretical sufficiency and indicated that the sampling phase was completed. This occurred separately for each of the two bodies of literature; viz., Gamification and Good Faith in Employment Law.

First, each item was read to provide an understanding of content. The items were viewed holistically and care was taken to preserve the flow of each document by avoiding truncation of key passages of text. Second, texts were carefully examined with annotations placed where keywords and potential themes emerged. The preliminary themes contained mainly descriptive underlying principles from the text. This decontextualised the data from the literature to identify previously unnoticed information, aided by a line-by-line analysis rather than holistic viewing. Third, the descriptive themes where collated into basic categories to illuminate other significant themes. The formation and iterative analysis allowed concepts to be re-analysed to determine how exactly each underlying theme was assigned to the specific categories; this process assists in highlighting meaning from the information and aids in defining the evolving themes. Fourth, the original texts were then approached with an analysis tasked with recontextualising the data with the assistance of the emerging themes - a process known as 'axial coding' (Corbin and Strauss, 1990).

\section{Results}

After initial sampling and analysis, two thematic category tables were created to represent the subsequent themes emerging from the 13 pieces of literature in each category. We are not claiming that these themes are the most important overall, or that they are relevant in all 
situations; however, we note these as they are within the scope and interest of an exploratory study (Appendix B). We first present each of the gamification and legal themes before we discuss how they interact such that a gamified employee motivation system may change the employer-employee relationship.

\subsection{Gamification themes}

Personalised Experience was perceived by both researchers and businesses to be an important aspect of an individualised gamification system. This may be crucial to the success of any system designed for long-term use; users are influenced by different motivational paradigms, which should be represented in any gamification implementations tasked with driving user behaviour (Paharia, 2013; Hamari et al., 2014). The exception is a system designed with the express intent of driving one-off task completion through the use of extrinsic rewards.

Increased Performance Feedback was closely connected to personalised experience, partially due to the requirements of motivational psychology (Ryan, Rigby, \& Przybylski, 2006) and the need to understand how well one is performing at a given task, which may influence feelings of effectiveness (Gagné \& Deci, 2005), along with business' desire to measure performance. This theme is significant within the context of legal implications under New Zealand employment legislation.

Raised Enterprise Prominence - many firms indicated they wished for more meaningful engagement with their staff to better achieve business objectives (Deterding, Sicart, Nacke, O'Hara, \& Dixon, 2011). Of particular note was the understanding each of the cases had towards enterprise gamification with the belief that it is an inevitable reality for most companies. There is a clear relationship between the use of enterprise gamification systems and the likelihood of unlawful or detrimental gamification implementations (Raftopoulos, 2014), especially with respect to obligations under New Zealand employment law for good faith.

Cognitive Dissonance is a recurrent state in which users or organisations hold conflicting views about gamification as a viable solution. Primarily, this stems from the limited understanding of human behaviour and motivation drivers (Ryan, Rigby, \& Przybylski, 2006; Statista, 2013). Concern was expressed over the effectiveness of extrinsic rewards for task completion and the possible negative effects these could have on intrinsic motivation focused systems (Pink, 2010). A gamification system designed in adherence to employment laws must ensure that any reward or action designed to direct behavioural change must abide by the obligations of 'good faith'.

Unintended Consequences relates to negative outcomes in initial business-oriented gamification implementations that were not intended (Callan et al., 2015). These consequences are likely due to the exploratory nature of most gamification implementations as the concept is still relatively new in business environments. System implementation occurs in an everchanging landscape, which subsequently has a direct impact on a company's ability to honour their legal employment obligations.

Generation Disparity relates to assumptions made about the future workforce being dominated by younger, tech-savvy staff (Vodanovich, Sundaram, \& Myers, 2010). These younger generations are believed to be more comfortable with gamification systems. However systems designed with generation disparity in mind should not be prohibitive to older 
generations or outliers. This is a best-practice design principle, rather than a legal obligation to serve all age groups equally.

Knowledge-Focused gamification systems revealed a movement towards business objectives to increase workforce skill levels through knowledge expansion. However, these systems have a tendency to lend themselves to traditional motivational theory (e.g., self-determination theory (Ryan \& Deci, 2000)), by providing challenges or enhancing users' drive to do better at a given task. This does not appear relevant to legal obligations.

Co-Produced Experience provides tasks outside of the standard role and usually in more socially-inclined environments with the goal of creating higher levels of user engagement and motivation in conjunction with others (La Guardia et al., 2000). This reflects the shift towards systems with peer-to-peer networks (Dimension Data, 2015). Co-produced experiences have limited legal implications for businesses using them as a motivational device; social workforce conduct must abide by the statutory obligations of good faith if behavioural change is desired.

Increased Stimulus was most evident in literature outlining systems that relied on methods of increased user performance by altering behaviours and perceptions of a given information system or work-related task. The notion of enhancing a user's positive desire to complete a task does not inherently introduce any new legal obligations. The legal focus should not be the desired enhancement, but rather how this is achieved.

Socially-Focused systems are a primary principle driving designs, often based on motivational types (Bartle, 1996), in consumer-focused systems with reliance on social interaction to facilitate and enhance the intrinsic value. As enterprise social networks become more prominent and best practice guides of gamification processes are followed, socially focused systems will play far more significant role and this may create the requirement to be able to disentangle a specific employee's performance from that of the wider group they work within.

Mitigating Monotony - with respect to relevance of legal obligations, there was little evident relationship between the requirements of mitigating monotony and adhering to legal obligations.

\subsection{Legal themes}

Social and Ethical Responsibility highlights the necessity to ensure reasonable steps are taken to act in an honest and consistent manner at all times. This is referred to as 'bona fides' and symbolises the sincere approach of parties engaged in any action and is core to the concept of "good faith" and translates immediately to the employment relationship. This theme was also evident in several common law cases each of which outlined obligations of social and ethical responsibility outside of strict adherence to legal rules.

Interpretation is Subject to Bias: as with the concept of 'bona fides', or honesty and frankness, it is apparent that the theme of subject bias in legal proceedings is prevalent. In much of the legal literature surrounding 'good faith', objective definitions of what constitutes an 'honest' approach appear elusive. Each ruling on the issue tended to deviate from or iterated on previous concepts, and in many instances, clear bias on behalf of the judiciary was present. Conflicting paradigms of those overseeing rulings are likely to play a significant role in the interpretation of gamification. 
International Influence: in some scenarios, the interpretation of good faith was subject to international influences, in part due to interconnected global norms on social and ethical responsibility and the biases present in a diverse background of judicial administrations. It is also observable that several international legislative systems have a similar approach to labour laws, especially in countries with a comparable legal heritage.

Contextual Difference relates to the legal system's reliance on the subjective definition of qualitative values. In multiple instances, how an obligation applied in a given situation was not based on the immediate description or previous definition, but instead upon the context in which the obligation was placed at the time. Of particular note were approaches towards the statutory duty to refrain from behaviour "likely to mislead or deceive", with numerous definitions given, and all with substantial differences and legal implications depending on their given context.

Higher Good Faith Obligation: this theme was less apparent than "contextual difference" and "social and ethical responsibility" in the literature, demonstrating that, even in instances where a good faith obligation has been observed by the parties, there may be in some situations an extended, or higher, expectation of what constitutes "good faith" behaviour. This is similar to the expectation for acts to be 'active and constructive', along with the concepts of 'bona fides' to ensure parties strive to the best of their ability to act in good faith.

Negligent Action or Inaction is one of the most recurrent themes in legal literature. It was central to many disputes under case law revolving around obligations of good faith, and attempts have been made at a statutory level to reduce the value of individuals disregarding their duties towards other parties, subject to their employment agreements. Negligent action or inaction was most observable when parties deviated from their duty to be "active and constructive", "communicative and responsive" and behaved in a way "likely to mislead or deceive".

\section{Discussion}

\subsection{The Relationship between 'Good Faith' and Gamification Systems}

Addressing the first research question (RQ1) requires an understanding of enterprise gamification systems and the nature of legislation about employment relationships; therefore, we first synthesise the two sets of themes to answer RQ1. Businesses must be aware of the connections between good faith and gamification systems: if unaccounted for, they could not only prohibit existing gamified processes from achieving their intended purpose, but also risk disrupting employment relationships while leaving companies vulnerable (Callan et al., 2015).

First, the design and implementation of gamified employee motivation systems must consider good faith, following the three key principles of being 'active and constructive', 'communicative and responsive', and refraining from actions 'likely to mislead or deceive'. In the case of negligent action or inaction, this obligation extends to a party's duty to proactively inform each other of any irregularities found in a gamification system. Further, this would extend to the manipulation of such systems through action or inaction to elevate false impressions of work performance or availability. Businesses must facilitate a personalised experience or provide increased performance feedback in a gamified system if it is actively monitored to prevent irregularities (e.g., public misrepresentations of an employee's performance) from being acted upon as part of the predictive behavioural analysis (Paharia, 
2013). Employees, too, have an obligation to ensure that systems are not intentionally manipulated in a way that would constitute misleading or deceptive behaviour.

What defines 'likely to mislead and deceive' is inherently subjective. As such, gamification requires consideration of the social and ethical responsibilities observable in both the judicial system and each individual actor, and also their ability to act with a higher degree of good faith obligation where it is to be reasonably expected. Such expectations will also stem from motivational drivers (e.g., use of self-determination theory (Ryan \& Deci, 2000) and how the system is used to influence employee behaviours. As a result of this contextual differentiation present in any given interpretation, it should be expect that not all examples of good faith actions will be directly transferable between systems or work environments.

Equally, employees and employers should understand that as gamification emerges, unintended consequences are expected. Ideally, businesses should communicate clearly and early with employees while gamification systems are developed and make efforts to open channels to discuss discrepancies and concerns in a proactive manner.

It is important to acknowledge that some unintended consequences of new gamification systems are likely to give rise to behaviours viewed as subjectively outside of employees' or employers' good faith obligations (Callan et al., 2015). This is due to the complex nature of human motivation and the lack of objective blanket definitions of 'good faith'. In some instances, cognitive dissonance towards a gamified-system, -process, or -behaviour may be the catalyst for complaints under good faith; the effect may be substantially mitigated by ensuring parties are receptive in their duty to be communicative and responsive.

By retroactively observing the lessons of Disneyland Anaheim in this light, three recommendations for the deployment of gamification implementations could be made based on these findings, addressing the second research question (RQ2).

First, informational displays must be carefully designed to ensure the accurate and fair representation of data appearing in public spaces about employees. This could be accomplished through the introduction of an intermediary party dedicated to reviewing and actively monitoring information appearing on public displays. Feedback from employees should be used to ensure there is a comprehensive review of how the information is used and understood and any behavioural consequences can be considered during deployment.

Second, given the subjective nature of good faith interpretations, it would be beneficial for employers to provide clear and definitive guidelines of what constitutes acceptable behaviour and conduct with respect to a gamified system. Ideally, these guidelines should be introduced in the initial employment agreement; however, instituting them into existing gamified systems is possible, providing effort is made to inform employees and they remain communicative and responsive.

Third, gamified systems should follow an 'opt-in' rather than an 'opt-out' policy. An opt-in policy would provide a safeguard for companies who acknowledge the inevitability of cognitive dissonance towards gamified systems by employees.

In summary, given these challenges, gamification principles in enterprise gamification systems must be carefully deployed, with extensive communication with employees during development and deployment. Efforts should be made to be transparent about the types of data and to seek employee feedback on the use and representation of the data. 


\subsection{Implications for Information System Managers}

Answering the second research question allows us to consider how gamification principles can be deployed in a gamification system, without negative consequences in the employment relationship.

IS managers and designers tasked with introducing enterprise gamified systems should be aware of ways to mitigate these effects by examining their obligations under 'good faith'. This has implications for the development and design phase of the system, where extensive consultation and feedback from employees will be valuable. It also influences how the information is provided and publicly made available, in a way that is tamper-proof and is immediately clear to the users what the displays are indicating. During system design, there should be consideration of job demands and job resources (Bakker et al., 2014) and how the appropriate data is displayed to employees, given these circumstances. Employers and employees could best interpret the naturally subjective intentions of the statutory requirements of good faith by ensuring the IS managers respond quickly to complaints about system intrusiveness, providing clear communication of problems, defining gathered/displayed performance metrics, and issuing clear 'good faith' codes of conduct.

\subsection{Limitations \& Future Research}

We based our arguments on New Zealand employment law and, although it is possible that our results will be generalisable to other common-law based jurisdictions (e.g., Australia and Canada), this conclusion rests on other researchers conducting a similar analysis of the relevant case law and statutes in those jurisdictions. While acknowledging that all jurisdictions have differences in the laws that they apply, we believe our results point to underlying issues that will be pertinent across the different countries.

The literature and legal cases analysed in this paper were purposively selected to highlight key themes. In particular, legal cases were selected on their relevance to obligations under the duty of good faith; however, in many instances these obligations were part of larger complaints or disputes; e.g., personal grievances for unjustified dismissal or unjustified disadvantage. These legal concepts were drawn from the New Zealand domestic legal system with minor affordances made for the influence of international rulings. As international influence emerged as a theme, this should be addressed in future research.

While legal analysis emphasises the importance of analysing all relevant cases from the high courts, instead of sampling, and of discussing the specific content of the cases, that method serves a different purpose than the thematic analysis presented here. The use of gamification in workplaces is a fairly new phenomenon, so the goal of the paper was to explore one aspect of the legal implications of this practice. Other aspects that we have not explored include the privacy implications of gamification; this is another area of concern for organisations since gamified employee motivation systems collect, use, and disclose information about individuals that may potentially cause them some loss or harm (Shahri et al., 2014). Another perspective that is worth exploring in the future is the effect of the use of gamification on the implied common law duties of mutual trust and confidence, fair dealing, and fair and reasonable treatment.

Further work is required to explore these issues, specifically pertaining to obligations under duty of good faith. While our exploration was limited, we have raised issues of adequate importance that a more comprehensive evaluation of case law revolving around personal 
grievances for unjustified dismissals and unjustified dismissal, such as the occurrence of misleading or deceitful behaviour, are likely to significantly contribute to subjective understanding of "good faith" behaviour.

Finally, this field of study would benefit substantially from examinations of employee perspectives on obligations of good faith within the employment relationship and other relevant areas of employment law. This would enhance our understanding of user resistance to deployed systems and how users perceive the advantages and disadvantages of gamification and may enable development of implementation- or practice-guides and selfhelp tools for managers.

\section{Conclusions}

Unlike much prior research that focuses on gamification from the perspective of improving user engagement or organisational performance (e.g. Liu, Santhanam, \& Webster, 2017), this paper examines its fit with an organisation's legal obligations to its employees. Gamification systems can offer many advantages for business and have the potential to stimulate higher levels of motivation among employees. The use of gamified systems can also be viewed as the next iterative step in customer and employee loyalty, where greater levels of satisfaction are obtained through true intrinsic value stimulation. However, it is equally clear that an inherently subjective legal system and statutory obligations under New Zealand employment law make it risky to deploy enterprise gamification systems. This paper's contribution lies in clarifying how the requirements under the duty of good faith introduces limitations on how and when gamification can be used by organisations, which come as a direct result of employment law's overarching goal of balancing the legal relationship between employees and employers.

To best mitigate the effects of good faith-based obligations on gamified systems, businesses should be mindful and proactive in following the three key principles for duty of good faith under New Zealand law. By being active and constructive, communicative and responsive and refraining from behaviour likely to mislead or deceive, they may reap the benefits of a gamified system while avoiding penalties for breaches under the Employment Relations Act 2000.

\section{References}

Aiello, J. R., \& K. J. Kolb. (1995). 'Electronic performance monitoring and social context: Impact on productivity and stress', Journal of Applied Psychology, 80, 3, 339-353.

Alder, G. S. (1998). 'Ethical issues in electronic performance monitoring: A consideration of deontological and teleological perspectives', Journal of Business Ethics, 17, 7, 729-743.

Annakis, J., Lobo, A., \& Pillay, S. (2011). ‘Exploring monitoring, work environment and flexibility as predictors of job satisfaction within Australian call centres', International Journal of Business and Management, 6, 8, 75-93. https://doi.org/10.5539/ijbm.v6n8p75

Baguley v Coutts Cars Ltd [2000] 2 ERNZ 409.

Bakker, A., Demerouti, E., \& Sanz-Vergel, A. I. (2014). 'Burnout and work engagement: The JD-R approach', Annual Review of Organizational Psychology and Organizational Behavior, $1,1,389-411$. 
Ball, K. S., \& S. T. Margulis. (2011). 'Electronic monitoring and surveillance in call centres: A framework for investigation', New Technology, Work and Employment, 26, 2, 113-126. doi:10.1111/j.1468-005X.2011.00263.x

Bandura, A., W. Freeman, \& R. Lightsey. (1999). 'Self-efficacy: The exercise of control', Journal of Cognitive Psychotherapy, 13, 2, 158-166.

Bartol, K. M., \& D. C. Martin. (1998), Management (3rd ed.). McGraw-Hill

Birks, M., \& J. Mills. (2011), Grounded theory: A practical guide: SAGE Publications Ltd.

Bogost, I. (2011). Persuasive Games: Exploitationware. Retrieved from http://www.gamasutra.com/view/feature/134735/persuasive_games_exploitationware. php?print $=1$

Callan, R. C., K. N. Bauer, \& R. N. Landers. (2015). How to avoid the dark side of gamification: Ten business scenarios and their unintended consequences. In T. Reiners \& L. C. Wood (Eds.), Gamification in Education and Business (pp. 553-568). Cham, Germany: Springer.

Carayon, P. (1994). 'Effects of electronic performance monitoring on job design and worker stress: Results of two studies', International Journal of Human-Computer Interaction, 6, 2, 177-190.

Chalykoff, J., \& T. A. Kochan. (1989). 'Computer-aided monitoring: Its influence on employee job satisfaction and turnover', Personnel Psychology, 42, 4, 807-834.

Chiles, A. M., \& T. E. Zorn. (1995). 'Empowerment in organizations: Employees' perceptions of the influences on empowerment', Journal of Applied Communication Research, 23, 1, 125.

Conley, K., \& C. Donaldson. (2015). Gamification: The measurement of benefits. In T. Reiners \& L. C. Wood (Eds.), Gamification in Education and Business (pp. 673-688). Cham, Germany: Springer. Retrieved from http://dx.doi.org/10.1007/978-3-319-10208-5_34. doi:10.1007/978-3-319-10208-5_34

Corbin, J. M., \& A. Strauss. (1990). 'Grounded theory research: Procedures, canons, and evaluative criteria', Qualitative Sociology, 13, 1, 3-21.

De Ruyter, K., M. Wetzels, \& R. Feinberg. (2001). 'Role stress in call centers: Its effects on employee performance and satisfaction', Journal of Interactive Marketing, 15, 2, 23-35.

Deery, S., \& N. Kinnie. (2002). 'Call centres and beyond: A thematic evaluation', Human Resource Management Journal, 12, 4, 3-13.

Department of Labour. (2006). Unjustified disadvantage: Developments in and examples from 2005. Retrieved 2015-07-28, from http://www.dol.govt.nz/er/services/law/case/themes/200602-unjustified-disadvantage.pdf

Deterding, S., D. Dixon, R. Khaled, \& L. Nacke. (2011a), From game design elements to gamefulness: Defining gamification Proceedings of the 15th International Academic MindTrek Conference: Envisioning Future Media Environments

Deterding, S., M. Sicart, L. Nacke, K. O'Hara, \& D. Dixon. (2011b), Gamification: Using gamedesign elements in non-gaming contexts CHI 2011 Conference on Human Factors in Computing Systems - Workshop on Gamification 
Dimension Data. (2015). Dimension Data's 2015 global contact centre benchmarking report. Retrieved September 17, 2017, from https://www.dimensiondata.com/Global/Downloadable Documents/2015 Global Contact Centre Benchmarking Summary Report.pdf

Dunham, R. B., J. A. Grube, \& M. B. Castañeda. (1994). 'Organizational commitment: The utility of an integrative definition', Journal of Applied Psychology, 79, 3, 370-380.

Employment Relations Act (2000). Retrieved from http://www.legislation.govt.nz/act/public/2000/0024/latest/DLM58333.ht $\underline{\mathrm{ml}}$

Gagné, M., \& E. L. Deci. (2005). 'Self-determination theory and work motivation', Journal of Organizational Behavior, 26, 4, 331-362.

Gaut v BP Oil New Zealand Ltd [2011] NZEmpC 71; (2011) 8 NZELR 687.

Global Sportsman Ltd v Mirror Newspapers [1984] 6 ATPR 45,339.

Grant, R. A., \& C. A. Higgins. (1991). 'Computerized performance monitors: Factors affecting acceptance', Engineering Management, IEEE Transactions on, 38, 4, 306-315.

Gwilt v Briggs and Stratton New Zealand Ltd [2011] NZEmpC 140; (2011) 9 NZELR 383.

Hallberg, L. R.-M. (2006). 'The "core category" of grounded theory: Making constant comparisons', International journal of qualitative studies on health and well-being, 1, 3, 141-148.

Hamari, J., Koivisto, J., \& Sarsa, H. (2014). ‘Does gamification work?--A literature review of empirical studies on gamification'. Paper presented at the 47th Hawaii International Conference on System Sciences, Waikoloa, HI.

Herzberg, F. (1966), Work and the nature of man. Cleveland OH: World Publishing.

Herzig, P., M. Ameling, \& A. Schill. (2015). Workplace psychology and gamification: Theory and application. In T. Reiners \& L. C. Wood (Eds.), Gamification in Education and Business (pp. 451-471). Cham, Germany: Springer. Retrieved from http://dx.doi.org/10.1007/9783-319-10208-5_23. doi:10.1007/978-3-319-10208-5_23

Holman, D. (2002). 'Employee wellbeing in call centres', Human Resource Management Journal, $12,4,35-50$.

Jeske, D., \& A. M. Santuzzi. (2015). 'Monitoring what and how: Psychological implications of electronic performance monitoring', New Technology, Work and Employment, 30, 1, 62-78. doi:10.1111/ntwe.12039

Kalleberg, A. L., \& K. A. Loscocco. (1983). 'Aging, values, and rewards: Explaining age differences in job satisfaction', American Sociological Review, 78-90.

Kumar, J. (2013), Gamification at work: Designing engaging business software. Berlin: Springer.

Kumar, R. (2005), Research methodology: A step-by-step guide for beginners. Los Angeles CA: SAGE.

La Guardia, J. G., R. M. Ryan, C. E. Couchman, \& E. L. Deci. (2000). 'Within-person variation in security of attachment: A self-determination theory perspective on attachment, need fulfillment, and well-being', Journal of personality and social psychology, 79, 3, 367-384. 
Lawless v Comvita New Zealand Ltd [2005] Employment Court, Auckland AC 77/05.

Lewig, K. A., \& M. F. Dollard. (2003). 'Emotional dissonance, emotional exhaustion and job satisfaction in call centre workers', European Journal of Work and Organizational Psychology, $12,4,366-392$.

Liu, D., Santhanam, R., \& Webster, J. (2017). 'Toward meaningful engagement: A framework for design and research of gamified information systems', MIS Quarterly, 41, 4, 10111034.

Lopez, S. (2011). Disneyland workers answer to 'electronic whip'. Retrieved 07/09/2014, 2014, from http://articles.latimes.com/2011/oct/19/local/la-me-1019-lopez-disney-20111018

Mehrotra, V. (1997). 'Ringing up big business', ORMS TODAY, 24, 18-25.

Mottaz, C. J. (1988). 'Determinants of organizational commitment', Human Relations, 41, 6, 467482.

National Distribution Union Inc v Carter Holt Harvey Ltd [2001] ERNZ 822.

Nee Nee v TLNZ Auckland Ltd [2006] Employment Court, Auckland AC 13/06.

New Zealand Cards Ltd v Ramsay [2012] NZEmpC 51.

NZ Amalgamated Engineering etc Union Inc v Carter Holt Harvey Ltd [2002] AC 53/02.

O'Hagan v Waitomo Adventures Ltd [2012] NZEmpC 161.

Paharia, R. (2013). Loyalty 3.0: How to revolutionize customer and employee engagement with big data and gamification. New York, NY: McGraw Hill Education.

Pink, D. H. (2010), Drive: The surprising truth about what motivates us. Edinburgh: Canongate.

R v Pier [1987] 1 NZLR 66.

Raftopoulos, M. (2014). 'Towards gamification transparency: A conceptual framework for the development of responsible gamified enterprise systems', Journal of Gaming E Virtual Worlds, 6, 2, 159-178.

Reiners, T., \& L. C. Wood. (2015), Gamification in Education and Business. Berlin: Springer.

Reiners, T., L. C. Wood, S. Gregory, \& H. Teräs. (2015). Gamification design elements in business education simulations. In M. Khosrow-Pour (Ed.), Encyclopedia of Information Science and Technology (3rd ed., pp. 3048-3061). Hershey, PA: Information Science Reference.

Ryan, R. M., \& E. L. Deci. (2000). 'Self-determination theory and the facilitation of intrinsic motivation, social development, and well-being', American Psychologist, 55, 1, 68-78.

Ryan, R. M., C. S. Rigby, \& A. Przybylski. (2006). 'The motivational pull of video games: A selfdetermination theory approach', Motivation and Emotion, 30, 4, 344-360.

Shahri, A., Hosseini, M., Phalp, K., Taylor, J., \& Ali, R. (2014, November). 'Towards a code of ethics for gamification at enterprise', in IFIP Working Conference on The Practice of Enterprise Modeling (pp. 235-245). Springer, Berlin, Heidelberg.

Shaw $v$ Schering-Plough Animal Health Ltd [2013] NZEmpC 22.

Sicart, M. (2008). 'Defining game mechanics', Game Studies, 8, 2, 1-14. 
Smith, M. J., P. Carayon, K. J. Sanders, S.-Y. Lim, \& D. LeGrande. (1992). 'Employee stress and health complaints in jobs with and without electronic performance monitoring', Applied Ergonomics, 23, 1, 17-27.

Stanton, J. M. (2000). 'Reactions to employee performance monitoring: Framework, review, and research directions', Human Performance, 13, 1, 85-113.

Taiapa v Te Runanga O Turanganuia A Kiwa Trust [2013] NZEmpC 38; 10 NZELR 378.

Tekinbas, K. S., \& E. Zimmerman. (2004), Rules of play: Game design fundamentals. Cambridge, MA: MIT Press.

Vodanovich, S., Sundaram, D., \& Myers, M. (2010). ‘Research commentary - Digital natives and ubiquitous information systems', Information Systems Research, 21, 4, 711-723.

Wallace, C. M., G. Eagleson, \& R. Waldersee. (2000). 'The sacrificial HR strategy in call centers', International Journal of Service Industry Management, 11, 2, 174-184.

Wickham, J., \& G. Collins. (2004). 'The call centre: A nursery for new forms of work organisation?', The Service Industries Journal, 24, 1, 1-18. doi:10.1080/02642060412331301102 


\section{Appendix A - Keywords used in literature search}

\begin{tabular}{|c|c|}
\hline Keywords & Relevance \\
\hline "gamification" & Provided a broad spectrum of literature on the topic of gamification \\
\hline "motivational psychology" & $\begin{array}{l}\text { Illuminated basic motivational principles leading to the discovery of Self } \\
\text { Determination Theory }\end{array}$ \\
\hline $\begin{array}{l}\text { "duty of good faith New } \\
\text { Zealand" }\end{array}$ & $\begin{array}{l}\text { Highlighted relevant aspects of NZ law with respect to "good faith" } \\
\text { obligations }\end{array}$ \\
\hline "defining game" & Provided academic literature around the definition of "game" \\
\hline “gamified system” & $\begin{array}{l}\text { Showed examples of current gamified systems in commercial and } \\
\text { enterprise settings }\end{array}$ \\
\hline
\end{tabular}




\section{Appendix B - Thematic categories and source documents}

Legal Themes

\begin{tabular}{llc}
\hline \multicolumn{1}{c}{ Thematic Category } & \multicolumn{1}{c}{ Classification Criteria } & $\begin{array}{c}\text { Number of source documents this } \\
\text { matched }\end{array}$ \\
\hline Social and Ethical Responsibility & $\begin{array}{l}\text { Instances of apparent social or } \\
\text { ethical implications in legal } \\
\text { interpretation } \\
\text { Instances of legal interpretation } \\
\text { subject to paradigm bias } \\
\text { Interpretation subject to bias }\end{array}$ & 4 \\
International Influence & $\begin{array}{l}\text { influenced by international } \\
\text { sovereigns } \\
\text { Instances of legal interpretation } \\
\text { definitions subject to given context } \\
\text { Instances where legal obligation } \\
\text { higher Good Faith Obligation }\end{array}$ & 2 \\
hegligent Action or Inaction & $\begin{array}{l}\text { Instances where legal definition a } \\
\text { result of negligence or inaction. }\end{array}$ & 5 \\
\hline
\end{tabular}

Gamification Themes

\begin{tabular}{|c|c|c|}
\hline Thematic Category & Classification Criteria & $\begin{array}{c}\text { Number of source documents this } \\
\text { matched }\end{array}$ \\
\hline Raised Enterprise Prominence & $\begin{array}{l}\text { Instances of increased enterprise } \\
\text { application }\end{array}$ & 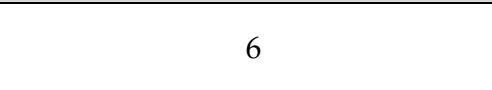 \\
\hline Personalised Experience & $\begin{array}{l}\text { Highlighted requirement to } \\
\text { personalise systems }\end{array}$ & 9 \\
\hline Increased Performance Feedback & $\begin{array}{l}\text { Highlighted importance of } \\
\text { increased feedback }\end{array}$ & 8 \\
\hline Mitigating Monotony & $\begin{array}{l}\text { Highlighted importance of self- } \\
\text { motivation }\end{array}$ & 4 \\
\hline Cognitive Dissonance & $\begin{array}{l}\text { Highlighted instances of } \\
\text { participants holding conflicting } \\
\text { views }\end{array}$ & 4 \\
\hline Unintended Consequences & $\begin{array}{l}\text { Highlighted unaccounted for } \\
\text { events in gamified systems }\end{array}$ & 7 \\
\hline Generation Disparity & Highlighted age considerations & 4 \\
\hline Knowledge focused & $\begin{array}{l}\text { Instances of knowledge focused } \\
\text { systems }\end{array}$ & 4 \\
\hline Co-produced Experience & $\begin{array}{l}\text { Instances of co-produced } \\
\text { experiences }\end{array}$ & 5 \\
\hline Increased Stimulus & Instances of stimulus focus & 6 \\
\hline Socially Focused & $\begin{array}{l}\text { Instances of Socially focused } \\
\text { system }\end{array}$ & 3 \\
\hline
\end{tabular}




\section{Appendix C - Literature used in thematic analysis}

Law Literature

(Global Sportsman Ltd v Mirror Newspapers, 1984)

(Rv Pier 1987)

(Baguley v Coutts Cars Ltd 2000)

(National Distribution Union Inc $v$ Carter Holt Harvey Ltd, 2001)

(Lawless $v$ Comvita New Zealand Ltd 2005)

(Nee Nee v TLNZ Auckland Ltd 2006)

(Gaut v BP Oil New Zealand Ltd, 2011)

(Gwilt v Briggs and Stratton New Zealand Ltd 2011)

(New Zealand Cards Ltd $v$ Greenbaum, J. (2012). Enterprise gamification ready to Ramsay, 2012)

\section{Gamification Literature}

Ryan, R. M., \& Deci, E. L. (2000). Self-determination theory and the facilitation of intrinsic motivation, social development, and well-being. American Psychologist, 55(1), 68-78.

Aparicio, A. F., Vela, F. L. G., Sánchez, J. L. G., \& Montes, J. L. I. (2012). Analysis and application of gamification. Paper presented at the Proceedings of the 13th International Conference on Interacción Persona-Ordenador.

Singh, S. (2012) Gamification: A strategic tool for organizational effectiveness. ANVESHAK-International Journal of Management, 1(1), 108-113.

Ryan, R. M., Rigby, C. S., \& Przybylski, A. (2006). The motivational pull of video games: A self-determination theory approach. Motivation and Emotion, 30(4), 344-360.

Landers, R. N., \& Callan, R. C. (2011). Casual social games as serious games: The psychology of gamification in undergraduate education and employee training In: M. Ma, A. Oikonomou, L. C. Jain, Serious Games and Edutainment Applications (pp. 399-423). Berlin: Springer.

Huotari, K., \& Hamari, J. (2012). Defining gamification: A service marketing perspective. Paper presented at the Proceeding of the 16th International Academic MindTrek Conference.

Epstein, Z. (2013) Enterprise Gamification for Employee Engagement. Retrieved 08/07/2015 from http://enterprisegamification.com/attachments/article/137/Enterprise $\% 2$ 0Gamification\%20Paper\%20-\%20Zoe\%20Epstein\%20\%20Ithaca\%20College.pdf

Deterding, S., Sicart, M., Nacke, L., O'Hara, K., \& Dixon, D. (2011). Gamification: Using game-design elements in nongaming contexts. CHI 2011 Conference on Human Factors in Computing Systems - Workshop on Gamification

make the collaborative dream real. Informationweek Online. 
(O'Hagan v Waitomo Adventures $L t d, 2012)$

(Shaw v Schering-Plough Animal Health Ltd, 2013)
Korolov, M. (2012). Gamification of the enterprise. Retrieved 28/07/2015 from http://www.networkworld.com/article/2160336/softwar e/gamification-of-the-enterprise.html

Thom, J., Millen, D., \& DiMicco, J. (2012). Removing gamification from an enterprise sns. Paper presented at the Proceedings of the ACM 2012 conference on Computer Supported Cooperative Work.

(Taiapa v Te Runanga O Zichermann, G., \& Cunningham, C. (2011). Gamification by Turanganuia A Kiwa Trust, 2013) Design: Implementing game mechanics in web and mobile apps. Sebastopol, CA: O'Reilly Media.

("Employment Relations Act," Deterding, S., Dixon, D., Khaled, R., \& Nacke, L. (2011). 2000) gamification. Paper presented at the Proceedings of the 15th International Academic MindTrek Conference: Envisioning Future Media Environments.

Copyright: (c) 2019 Hinton, Wood, Singh \& Reiners. This is an open-access article distributed under the terms of the Creative Commons Attribution-NonCommercial 3.0 Australia License, which permits non-commercial use, distribution, and reproduction in any medium, provided the original author and AJIS are credited.

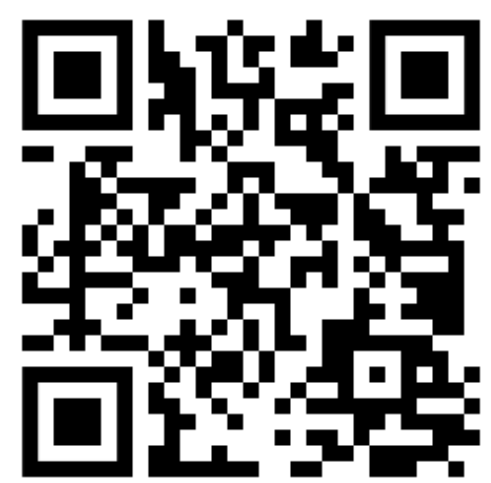

